\title{
Li-Co-Ni-Mn-(REE) veins of the Western Erzgebirge, Germany-a potential source of battery raw materials
}

\author{
Mathias Burisch ${ }^{1,2}\left(\right.$ Max Frenzel $^{2} \cdot$ Henning Seibel $^{1} \cdot$ Albert Gruber $^{3} \cdot$ Marcus Oelze $^{4} \cdot$ Jörg A. Pfänder $^{5}$. \\ Cynthia Sanchez-Garrido ${ }^{2}$ Jens Gutzmer ${ }^{1,2}$
}

Received: 29 December 2020 / Accepted: 31 May 2021 / Published online: 25 June 2021

(c) The Author(s) 2021

\begin{abstract}
Situated in the western Erzgebirge metallogenetic province (Vogtland, Germany), the Eichigt prospect is associated with several quartz-Mn-Fe-oxyhydroxide veins that are exposed at surface. Bulk-rock geochemical assays of vein material yield high concentrations of $\mathrm{Li}(0.6-4.1 \mathrm{~kg} / \mathrm{t}), \mathrm{Co}(0.6-14.7 \mathrm{~kg} / \mathrm{t})$, and $\mathrm{Ni}(0.2-2.8 \mathrm{~kg} / \mathrm{t})$, as well as significant quantities of Mn, $\mathrm{Cu}$, and light rare earth elements, a very unusual metal tenor closely resembling the mixture of raw materials needed for Li-ion battery production. This study reports on the results of a first detailed investigation of this rather unique polymetallic mineralization style, including detailed petrographic and mineralogical studies complemented by bulk rock geochemistry, electron microprobe analyses, and laser ablation inductively coupled mass spectrometry. The mineralized material comprises an oxide assemblage of goethite hematite, hollandite, and lithiophorite that together cement angular fragments of vein quartz. Lithiophorite is the predominant host of $\mathrm{Li}(3.6-11.1 \mathrm{~kg} / \mathrm{t}), \mathrm{Co}(2.5-54.5 \mathrm{~kg} / \mathrm{t})$, and Ni $(0.2-8.9 \mathrm{~kg} / \mathrm{t}) ; \mathrm{Cu}$ is contained in similar amounts in hollandite and lithiophorite whereas light rare earth elements (LREE) are mainly hosted in microcrystalline rhabdophane and florencite, which are finely intergrown with the $\mathrm{Mn}$-Fe-oxyhydroxides. ${ }^{40} \mathrm{Ar} /{ }^{39} \mathrm{Ar}$ ages ( 40-34 Ma) of coronadite group minerals coincide with tectonic activity related to the Cenozoic Eger Graben rifting. A low-temperature hydrothermal overprint of pre-existing base metal sulfide-quartz mineralization on fault structures that were reactivated during continental rifting is proposed as the most likely origin of the polymetallic oxyhydroxide mineralization at Eichigt. However, tectonically enhanced deep-reaching fracture-controlled supergene weathering cannot be completely ruled out as the origin of the mineralization.
\end{abstract}

Keywords Lithiophorite $\cdot$ Coronadite group $\cdot$ Hollandite $\cdot$ Cryptomelane $\cdot 40$ Ar/39Ar geochronology $\cdot$ Trace elements · Lithium $\cdot$ Manganese $\cdot$ Cobalt $\cdot$ Exploration $\cdot$ Raw materials

\section{Introduction}

Editorial handling: A. Cabral/S. Hagemann.

Mathias Burisch

mathias.burisch@mineral.tu-freiberg.de

1 TU Bergakademie Freiberg, Institut Für Mineralogie, Brennhausgasse 14, 09599 Freiberg, Germany

2 Helmholtz Zentrum Dresden-Rossendorf, Helmholtz Institute Freiberg for Resource Technology, Chemnitzer Str. 40, 09599 Freiberg, Germany

3 Lithium Australia NL, Level 1, 675 Murray Street, West Perth, WA 6005, Australia

4 German Research Centre for Geosciences, GFZ, Telegrafenberg, 14473 Potsdam, Germany

5 TU Bergakademie Freiberg, Institut Für Geologie, Bernhard-von-Cotta-Str. 2, 09599 Freiberg, Germany
Lithium, nickel, manganese, and cobalt are essential raw materials for the production of rechargeable Li-ion batteries, a critical component in the transition to electromobility and energy storage in a renewable energy system (UNCATAD, 2020). While these raw materials are produced from a variety of ore deposit types, none is currently known to contain all four in concentrations sufficient for economic extraction (Verplanck and Hitzman, 2016).

In search of unexplored and unconventional Li resources, Lithium Australia NL recently acquired an exploration license in the Eichigt area, Germany (Gruber (2018); Fig. 1A). Within the license area, several NW-SE trending vein structures can be traced at surface (Fig. 1B and Fig. 2A). In surface exposure, the vein material consists of 
Fig. 1 (A) Geological overview map of the Erzgebirge (modified after Sächsisches Landesamt für Umwelt (1994)). (B) Detailed map of the Eichigt area including the sample localities and inferred vein orientations.
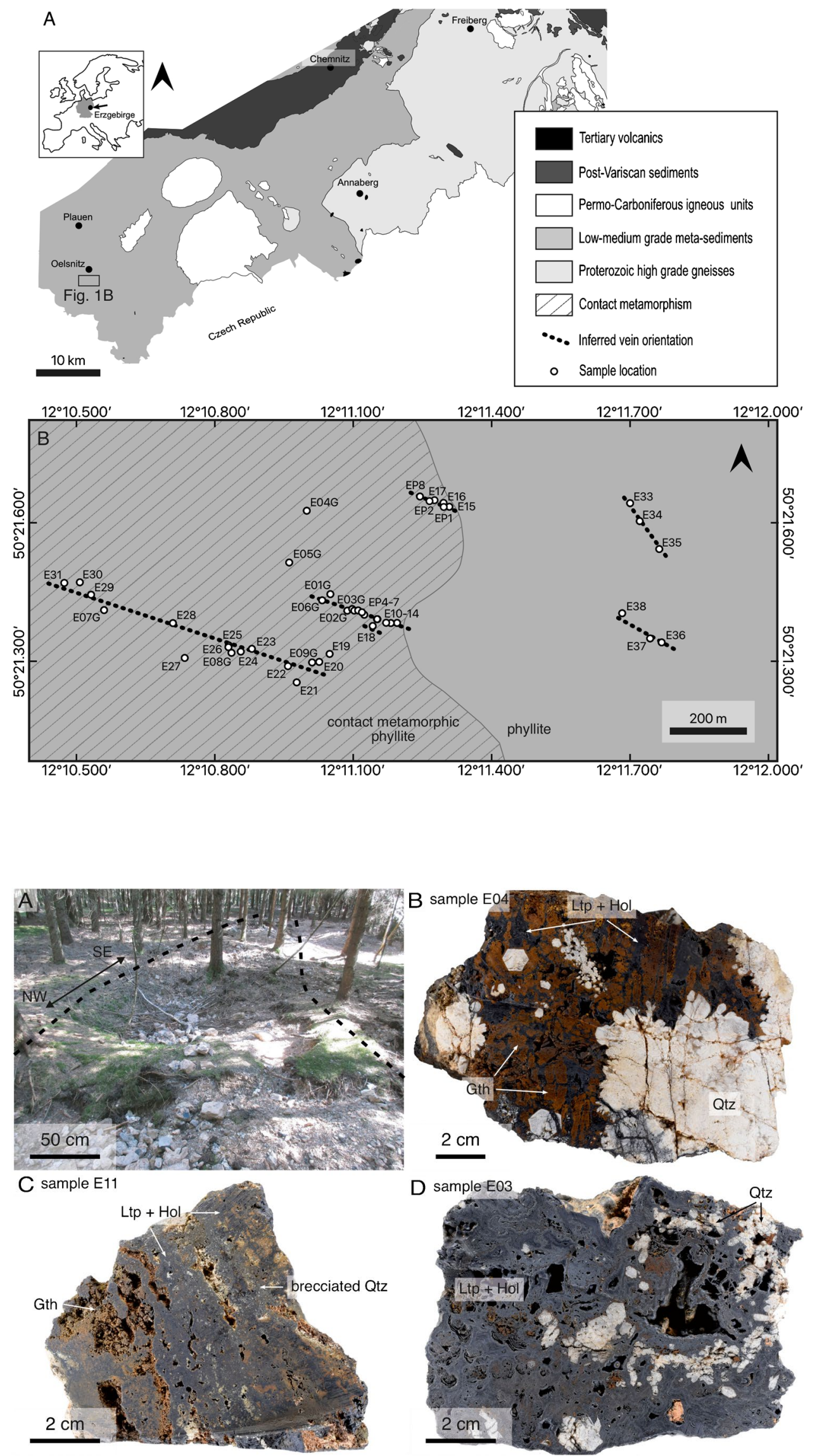
float fragments of vein quartz as well as decimeter-sized masses of $\mathrm{Fe}-\mathrm{Mn}$ oxides marked by the particular abundance of lithiophorite and coronadite group minerals. Although historic mining activity in the Eichigt area is poorly documented, shallow pits and small dumps across the whole area provide evidence of some historic exploitation. Recent reconnaissance studies of Lithium Australia NL show that composite samples of the mineralized material contain significant quantities of $\mathrm{Li}, \mathrm{Co}$, and $\mathrm{Mn}$ as well as $\mathrm{Ni}, \mathrm{Cu}, \mathrm{Zn}$, and light rare earth elements (Gruber, 2018) qualifying it as a potential source for battery raw materials. Apart from the recent geochemical assays carried out by Lithium Australia, this newly recognized style of Li-Co-Mnoxyhydroxide mineralization remains unexplored in terms of its resource potential.

Here, we present new petrographic (microscopic, SEM), mineralogical (XRD), and geochemical data (EPMA, LAICP-MS, and bulk ICP-MS) along with ${ }^{40} \mathrm{Ar} /{ }^{39} \mathrm{Ar}$ geochronological analyses on mineralization at the Eichigt prospect in the Western Erzgebirge, Germany. Our goal is to better characterize the unusual style of mineralization and contribute to the understanding of its metallogenesis.

\section{Background information}

\section{Lithiophorite and coronadite group minerals}

Lithiophorite - $(\mathrm{Li}, \mathrm{Al}) \mathrm{Mn}^{4+} \mathrm{O}_{2}(\mathrm{OH})_{2}$ — was first described by Frenzel (1870) in samples from the Schneeberg polymetallic vein district in Erzgebirge. Lithiophorite usually occurs not only as crusts, impregnations, and disseminations, but also as colloform and botryoidal infills, often accompanied by minerals of the coronadite group (Crespo and Lunar, 1997; De Villiers, 1945; Ostwald, 1984). The members of the coronadite group minerals, in contrast, have the generalized formula $\mathrm{A}_{2-\mathrm{y}} \mathrm{B}_{8-\mathrm{z}} \mathrm{O}_{16}$ with $\mathrm{y}<1$ and $\mathrm{z}=0.1$ to 0.5 (Biagioni et al., 2012; Frenzel, 1980). The B site is predominantly occupied by Mn (both as tetravalent and trivalent cations), usually with minor contents of $\mathrm{Fe}^{3+}$ and other transition metal cations. The A site, on the other hand, is typically occupied by large mono- and di-valent cations. The different members of the coronadite group (also called psilomelane group by Frenzel (1980)) are named according to the predominant cation on the A site, such as hollandite $\left(\mathrm{Ba}^{2+}\right)$, cryptomelane $\left(\mathrm{K}^{+}\right)$, coronadite $\left(\mathrm{Pb}^{2+}\right)$, and manjiroite $\left(\mathrm{Na}^{+}\right)$.

Both lithiophorite and coronadite group minerals are abundant in weathered manganiferous rocks and manganese ores from all over the world. Some examples include the Postmasburg Mn deposit in South Africa (De Villiers, 1945; Gutzmer and Beukes, 1996); the Pilbara Manganese Province, Australia (Jones, 2017; Ostwald, 1984); the Nkamouna laterite, SE Cameroon (Dzemua et al., 2013); Eastern Ghats
Mn deposit, India (Rao et al., 2010); and Ni-laterites of New Caledonia, France (Manceau et al., 1987). Vein-hosted oxyhydroxide mineralization of hydrothermal origin containing both lithiophorite and coronadite group minerals, on the other hand, is rather rare (Nicholson, 1992). Only a small number of examples are reported, which include the Erzgebirge (Ilgner and Hahn, 1998; Kuschka, 1997), Germany, Lusatia, Germany (Giesler et al., 2017), the Calatrava Volcanic Field, Spain (Crespo and Lunar, 1997), and the Quinn Canyon Range, Nye County, USA (Hewett et al., 1968).

There are numerous smaller showings of Fe-Mn-oxyhydroxides in Germany (Hautmann and Lippolt, 2000). These are invariably associated with Variscan basement units that have been exhumed as a consequence of Cenozoic tectonics (Hautmann and Lippolt, 2000; Pälchen and Walter, 2008). Hautmann and Lippolt (2000) have dated many of these showings by ${ }^{40} \mathrm{Ar} /{ }^{39} \mathrm{Ar}$ geochronology on coronadite group minerals, yielding ages between $\sim 25$ and $1 \mathrm{Ma}$. This dataset includes samples from the Schwarzenberg and the Geyer districts (Erzgebirge) having ages of $18.22 \pm 0.49$ and $7.05 \pm 0.09 \mathrm{Ma}$, respectively.

\section{Geology of the Erzgebirge}

The Erzgebirge is an erosional window comprising predominantly metamorphic nappes (Kröner and Willner, 1998; Roetzler et al., 1998) of Proterozoic to Early Paleozoic lithological units of the Variscan crystalline basement (Pälchen and Walter (2008); Fig. 1A). Metamorphic units generally decrease in their metamorphic grade from ortho- and paragneisses in the East to mica-schists and phyllites in the West (Fig. 1A). Subsequent to peak metamorphism at ca. 340 Ma, the metamorphic rocks of the Variscan basement have been intruded/covered by late to post collisional magmatic and (sub)volcanic units (Štemprok, 1967). Concomitantly, the Erzgebirge block was rapidly exhumed (Kröner and Willner, 1998) during the late orogenic stage. Permian rifting and collapse of the Variscan Orogen (295-285 Ma) coincided with large-scale extensional tectonics and voluminous volcanism, resulting in subsidence and burial of the Variscan units by younger sediment successions. Only much later, rifting and uplift related to the Cenozoic Eger graben rifting resulted in exhumation of the Erzgebirge block (Ziegler and Dèzes, 2007).

The Erzgebirge hosts a large variety of ore deposit types (Baumann et al., 2000). Ore formation is associated with several distinct geotectonic events, which are related to (a) late stages of the Variscan Orogeny (Burisch et al., 2019a; Zhang et al., 2017), (b) Permian Rifting (Burisch et al., 2019a; Ostendorf et al., 2019), (c) the opening of the northern Atlantic (Bauer et al., 2019; Guilcher et al., 2021a; Haschke et al., 2021; Ostendorf et al., 2019), and (d) the Cenozoic Eger graben rifting (Guilcher et al., 2021a; 
Hautmann and Lippolt, 2000). Hot springs and geothermal wells are a record of ongoing hydrothermal activity related to the Eger graben rifting (Dupalová et al., 2012; Paces and Smejkal, 2014; Vylita et al., 2007).

Structurally controlled Mn- and Fe-oxyhydroxide mineralization is widespread across the Erzgebirge (Baumann et al., 2000; Kuschka, 2002). Two different types of Fe-Mnoxyhydroxides assemblages have been recognized: irondominated crusts and masses related to surficial oxidation zones of siderite-bearing hydrothermal veins (Kuschka, 2002). Partial replacement of siderite and sulfide minerals by Fe-oxyhydroxides with remnants of primary minerals and pseudomorphous textures is a common characteristic of this mineralization style (Kuschka, 2002). Mn-rich oxyhydroxide-rich vein mineralization has also been described (Kuschka, 2002). The majority of such Mn oxyhydroxide mineralization occurs as open-space infill, which covers, cross-cuts, or brecciates older hydrothermal mineral stages. Pseudomorphous textures are rather rare in the latter type of Mn-oxyhydroxides. Prior to the recognition of the textural differences and the discovery of Mn-oxyhydroxide vein intersection of a drill core (Ktr 23 A2/81) at $525 \mathrm{~m}$ depth below the surface at Brunndöbra in the 1980s (Ilgner and Hahn, 1998), it was assumed that all $\mathrm{Fe}-\mathrm{Mn}$-oxyhydroxide showings in the Erzgebirge are of supergene origin. After this discovery, Kuschka (2002) argued that at least some of these $\mathrm{Fe}-\mathrm{Mn}$-oxyhydroxides must be of low-temperature hydrothermal origin, since they occur significantly below the zone of paleo- and recent weathering (Migon and LidmarBergström, 2001).

\section{Geology of the Eichigt area}

Eichigt is situated in the western part of the Variscan Erzgebirge basement window (locally referred to as the Vogtland). The host rocks exposed at the Eichigt prospect are invariably phyllites (Fig. 1A and B), comprising muscovite and quartz as major components and belonging to the Pycoden Supergroup (Pälchen and Walter, 2008). Following Variscan regional metamorphism, the phyllites exposed in the Eichigt prospect area locally underwent contact metamorphic overprint (Schuppan, 1968), resulting in a low-grade contact aureole (Fig. 1A) related to the Schönbrunn granitoid intrusion. This intrusion occurs at $500-750 \mathrm{~m}$ below the surface of the Eichigt area (Tischendorf et al., 1965): a medium-F peraluminous, monzo- to syenogranite moderately enriched in Li and highly enriched in light rare earth elements (LREE) (Gottesmann et al., 2017). The granite has been age dated with Th-U-Pb of uraninite to $306 \pm 3 \mathrm{Ma}$ (Gottesmann et al., 2017). At the surface, the contact metamorphism can be noted only by the presence of chlorite-sericite porphyroblasts (Schuppan, 1968). The boundary of the contact aureole strikes approximately N-S across the prospect (Fig. 1B). In the SW of the Eichigt prospect area, there is an exposure of pipe-like intrusions of basaltoid volcanic rocks; these are thought to be related to Cenozoic magmatic activity during the Eger graben rifting (Pälchen and Walter, 2008; Ulrych et al., 2011).

\section{Sampling and methods}

Fifty-eight samples were collected from 33 locations within the Eichigt license area (Fig. 1B and electronic supplement Table A1). Hand specimens have diameters between 15 and $40 \mathrm{~cm}$. All mineralized samples were collected as float from historic surface mine workings. Most of the samples represent the vein assemblage, but a few samples of host rock were also collected (Electronic supplement Table A1). All samples were cut and prepared at the Helmholtz-Institute Freiberg for Resource-Technology (HIF).

\section{Microscopy}

Transmitted and reflected light microscopy were conducted on eleven polished thin sections at the Light Microscopy Laboratory of the Institute of Mineralogy, TU Bergakademie Freiberg, using a ZEISS Axio Imager M1m microscope. Microphotographs were taken with a ZEISS AxioCam MRc5 at a resolution of $2584 \times 1936$ pixels.

\section{Scanning electron microscopy}

Scanning electron microscopy (SEM) was conducted at the analytical laboratories of the HIF. A FEI Quanta 650 MLA-FEG scanning electron microscope equipped with two Bruker Quantax X-Flash 5030 energy dispersive X-ray spectroscopy (EDS) detectors was used for imaging and singlegrain energy-dispersive X-ray analyses.

\section{X-ray powder diffraction}

Ten samples were analyzed for qualitative mineral identification by X-ray powder diffraction (XRD) at the HIF. Analyses were conducted using a PANalytical Empyrean (radius $240 \mathrm{~mm}$ ) X-ray diffractometer equipped with a Co $\mathrm{X}$-ray source, automatic divergence aperture, and two detectors (proportional counter with monochromator and PIXcel 3-D Medipix $1 \times 1$ semiconductor detector with Fe-filter). A measurement time of $9 \mathrm{~h}$ was used to achieve optimal peak to background ratios. 


\section{Whole-rock geochemistry}

A total of 58 samples with variable modal abundances of $\mathrm{Fe}-\mathrm{Mn}$-oxyhydroxides (0.5-80 vol\%) from 26 individual localities were analyzed with four-acid digestion ICP-MS (ME-MS61 and ME-ICP61a) and aqua regia digestion ICPMS (ME-MS41) for major, minor, and trace elements at ALS laboratories, Canada. Three host rock samples were analyzed for major, minor, and trace elements using a combination of instrumental neutron activation analyses (INAA) and $\mathrm{N}_{2} \mathrm{O}_{2}$ digestion ICP-MS at Activation Laboratories Ltd., Canada. Detection limits for each method are included in Table A1 of the electronic supplement.

\section{Electron-probe microanalyzer}

Lithiophorite and coronadite group mineral compositions were quantified by electron probe microanalysis (EPMA) at the HIF using a JEOL JXA-8530F equipped with a field emission gun and five wavelength-dispersive spectrometers. An accelerating voltage of $20 \mathrm{kV}$ and a beam current of 30 nA were used. Astimex Ltd. reference materials of magnetite, plagioclase, cobalt, and benitoite were used for calibration and were analyzed regularly as unknowns after $\sim 100$ spots to monitor potential instrument drift. Peak overlap and ZAF matrix corrections were carried out as described in Osbahr et al. (2015). Subsequently, major elements with concentrations $>10 \mathrm{wt}$. \% were incrementally corrected for machine drift assuming linear drift between every two standard blocks. Concentrations below the limit of quantification (3.4 times the detection limit given by the JEOL software) were excluded from the dataset. Furthermore, elemental concentrations with a relative 3-sigma standard deviation exceeding $40 \%$ were excluded from the dataset to increase the reliability of results with low elemental concentrations. A total of 343 spot analyses were carried out (Electronic supplement Table A2), but only the Mn contents are used in this manuscript - all other data used here are from LAICP-MS analyses (see below).

\section{Laser ablation inductively coupled plasma mass spectrometry}

Minor and trace element concentrations in lithiophorite and coronadite group minerals were analyzed by laser ablation inductively coupled plasma mass spectrometry (LAICP-MS). A Teledyne Excite $193 \mathrm{~nm}$ analyte excimer laser coupled to an iCAP RQ inductively coupled quadrupole mass spectrometer at the German Research Center for Geosciences in Potsdam (GFZ) was used for these analyses.

The ablation spot size was set to $40 \mu \mathrm{m}$, with a laser repetition rate of $10 \mathrm{~Hz}$ and fluence at the sample surface of $\sim 2-3 \mathrm{~J} / \mathrm{cm}^{2}$. Short washout times of the laser aerosol were achieved by the use of a two-volume cell. Ablation was performed in an atmosphere of pure $\mathrm{He}(\sim 0.7 \mathrm{~L} / \mathrm{min})$. The analysis time for each sample was $50 \mathrm{~s}$, with $20 \mathrm{~s}$ for background measurement (laser off) and $30 \mathrm{~s}$ of signal analysis with laser on. The following isotopes were measured: ${ }^{6} \mathrm{Li},{ }^{7} \mathrm{Li},{ }^{23} \mathrm{Na}$, ${ }^{24} \mathrm{Mg},{ }^{25} \mathrm{Mg},{ }^{26} \mathrm{Mg},{ }^{27} \mathrm{Al},{ }^{29} \mathrm{Si},{ }^{31} \mathrm{P},{ }^{33} \mathrm{~S},{ }^{34} \mathrm{~S},{ }^{39} \mathrm{~K},{ }^{43} \mathrm{Ca},{ }^{44} \mathrm{Ca}$, ${ }^{51} \mathrm{~V},{ }^{52} \mathrm{Cr},{ }^{53} \mathrm{Cr},{ }^{55} \mathrm{Mn},{ }^{57} \mathrm{Fe},{ }^{59} \mathrm{Co},{ }^{60} \mathrm{Ni},{ }^{62} \mathrm{Ni},{ }^{63} \mathrm{Cu},{ }^{65} \mathrm{Cu}$, ${ }^{66} \mathrm{Zn},{ }^{67} \mathrm{Zn},{ }^{71} \mathrm{Ga},{ }^{75} \mathrm{As},{ }^{85} \mathrm{Rb},{ }^{86} \mathrm{Sr},{ }^{88} \mathrm{Sr},{ }^{95} \mathrm{Mo},{ }^{107} \mathrm{Ag},{ }^{109} \mathrm{Ag}$, ${ }^{111} \mathrm{Cd},{ }^{137} \mathrm{Ba},{ }^{182} \mathrm{~W},{ }^{205} \mathrm{Tl},{ }^{206} \mathrm{~Pb},{ }^{207} \mathrm{~Pb},{ }^{208} \mathrm{~Pb},{ }^{238} \mathrm{U}$.

Manganese concentrations determined by EPMA were used as internal standard, with NIST SRM 610 as the external standard material. Two further reference materials (MACS-3, GSE-2G) were measured as known unknowns to evaluate the measurement quality (Electronic supplement Table A3). Standard blocks were inserted after every 10 unknown analyses. Time intervals for data reduction were selected by visual inspection of each spectrum using the Iolite $^{\mathrm{TM}}$ software package (Paton et al., 2011). Uncertainty estimates for the measured elements are based on accuracy and precision of the reference materials measured as secondary standards. Cobalt concentrations were determined with both methods and are consistent (within 10\% relative error) for each spot analysis.

\section{${ }^{40} \mathrm{Ar} /{ }^{39} \mathrm{Ar}$ geochronology}

Sample fragments of composite Mn-oxyhydroxides (mainly of hollandite, member of the coronadite group) were handpicked, crushed, and sieved. The $250-500-\mu \mathrm{m}$ size fractions were then repeatedly washed in deionized water in an ultrasonic bath to remove any fine-grained particles and dust. After drying, the samples were wrapped in $\mathrm{Al}$ foil and loaded along with fluence monitors in wells of an $\mathrm{Al}$ disc (33 $\mathrm{mm}$ diameter) for irradiation. The latter was done for $17.75 \mathrm{~h}$ in the rotational facility of the LVR-15 research reactor of the Centrum Výzkumu Řež (CV̌̌), Czech Republic. The thermal $(<0.5 \mathrm{eV})$, fast $(>1 \mathrm{MeV})$, and total neutron fluence rates have been $\sim 3.7 \times 10^{13} \mathrm{n} / \mathrm{cm}^{2} \mathrm{~s}, \sim 7.5 \times 10^{12} \mathrm{n} /$ $\mathrm{cm}^{2} \mathrm{~s}$, and $\sim 7.6 \times 10^{13} \mathrm{n} / \mathrm{cm}^{2} \mathrm{~s}$ at a reactor power of $8.2 \mathrm{MW}$. After irradiation, the samples were unwrapped and $\sim 18 \mathrm{mg}$ was loaded into a 7-mm-diameter well on an oxygen-free copper disc for laser step heating. The latter was performed using a 25-W Synrad $\mathrm{CO}_{2}$-laser coupled to a Raylase Scanhead for beam deflection. Deflection frequencies were 55 and $300 \mathrm{~Hz}$ on the $\mathrm{x}$ and $\mathrm{y}$ axes, and the amplitude of the Scanhead was set to cover the whole sizes of a well. Gas purification was achieved by two SAES NP10 getter pumps, one at room temperature and one at $\sim 400{ }^{\circ} \mathrm{C}$. Heating and cleaning times were $3 \mathrm{~min}$ and 5 min per step. Argon isotope compositions were measured in multi-dynamic mode on a Thermo ARGUS VI noble gas mass spectrometer equipped with five faraday cups $\left(10^{11} \Omega\right.$ resistor at position $\mathrm{H} 2,10^{12} \Omega$ resistors at positions $\mathrm{H} 1$ to L2) and a CDD 
multiplier at the low mass side (L3). The intercalibration of the CDD was done externally during air-shot measurements and relatively to the L2 Faraday cup using a beam current of about 25-40 fA on mass 36. Typical blank levels range between $0.5 \times 10^{-16}$ to $1.4 \times 10^{-16} \mathrm{~mol}^{40} \mathrm{Ar}$ and $1.0 \times 10^{-18}$ to $3.4 \times 10^{-18} \mathrm{~mol}^{36} \mathrm{Ar}$. Twenty cycles with a total duration of $\sim 9$ min were measured per temperature step. Each cycle comprised two acquisition sequences with masses 38 and 39 on the axial cup, respectively, and 8.4-s integration time plus 5.0-s delay time per sequence. For time-zero intercept calculation, and blank-, mass-bias, and interference corrections, an in-house developed Matlab ${ }^{\circledR}$ toolbox was used. Mass bias was corrected assuming linear mass-dependent fractionation and using an atmospheric ${ }^{40} \mathrm{Ar} /{ }^{36} \mathrm{Ar}$ ratio of $298.6 \pm 0.3$ (Lee et al., 2006). Isochron, inverse isochron, and weighted mean average (plateau) ages have been calculated using ISOPLOT 3.7 (Ludwig, 2008). All ages were calculated relative to the in-house standard DRF1 (Drachenfels sanidine) as a fluence monitor with an age of $25.682 \pm 0.030 \mathrm{Ma}$, calibrated against a Fish Canyon Tuff sanidine age of $28.305 \pm 0.036 \mathrm{Ma}$ (Renne et al., 2010). All reported errors are $1 \sigma$. Interference correction factors are given in the supplementary dataset.

\section{Results}

The following subsections include brief descriptions of the observed field relationships and microscopic features of the sample material. Furthermore, summaries of whole-rock geochemical analyses, mineral microanalyses, and ${ }^{40} \mathrm{Ar} /{ }^{39} \mathrm{Ar}$ geochronology are presented.

\section{Field observations}

Although the veins are not directly exposed at the surface due to vegetation and soil cover, their orientation is inferred from historic surface mine workings and the distribution of float rocks (Fig. 2A). Mineralized rock fragments occur in float within 0.5- to 2-m-wide anastomosing zones that typically trend NW-SE (Fig. 1B) and that likely coincide in extent and orientation to veins in the subsurface. Veins are hosted by fine-grained phyllites, which are mainly composed of muscovite and quartz. Silicified vein selvages occur; these are several centimeters thick and usually appear bleached or hematitized.

Hydrothermal quartz is ubiquitous in mineralized float rocks (Fig. 2B-D), often forming euhedral crystals up to several centimeters long (Fig. 2B). Samples revealing host rock brecciation are common. Black and brown Mn-Feoxyhydroxides occur not only as abundant massive cavity and fracture infills but also as impregnations within host rock and fine-grained quartz (Fig. 2A-D). The modal abundance of the $\mathrm{Mn}$-Fe-oxyhydroxides in the float fragments is variable, and ranges mostly between $\sim 10$ and $30 \mathrm{vol} . \%$, in some cases reaching more than $50 \mathrm{vol} . \%$.

\section{Mineralogy and petrography}

Below, we briefly describe the various paragenetic stages in the veins recognizable from the available samples. These descriptions are based on an integration of optical microscopic observations with SEM and XRD analyses (representative X-ray diffractograms are provided in Fig. A1 of the electronic supplement). Figure 3 gives an overview of representative ore textures, and Fig. 4 summarizes the paragenetic relationships.

\section{Stage I: Quartz}

Hydrothermal quartz is the predominant constituent (20 to 90 vol.\%) of the vein samples (Fig. 2B). All quartz is milky white and clearly pre-dates the $\mathrm{Fe}-\mathrm{Mn}$-oxyhydroxide mineralization (Fig. 3A, B, E). Brecciation of vein quartz is common, ranging from subordinate to intense (Fig. 2B, C).

\section{Stage II: Iron-oxyhydroxides}

Goethite and hematite are invariably the oldest oxyhydroxide minerals. They are present as botryoidal and arboriform aggregates and colloform crusts, enclosing hydrothermal quartz of stage I and host rock fragments (Fig. 3A). Goethite is typically more abundant than hematite. The combined modal abundances of goethite and hematite range from 5 to $25 \mathrm{vol}$.\%. Brecciation of the Fe-oxyhydroxide aggregates is common.

\section{Stage III: Mn-oxyhydroxides}

Mn-oxyhydroxides occur as colloform crusts and vein-infill, comprising mainly lithiophorite and coronadite group minerals (from now on referred to as hollandite since it is the main endmember in the investigated samples) that postdate the Fe-oxyhydroxide assemblage of stage II (Fig. 3A, G, F, G). Composite masses of Mn-oxyhydroxides occur as irregularly shaped or less commonly angular void infills that grow from rim to center but they also may form individual veinlets cross-cutting previous mineralization stages and the host rock. Rarely, pseudomorphs of Mn-oxyhydroxides after an unknown rhombohedral precursor mineral are recognized.

Hollandite is commonly the first mineral of stage III to overgrow the $\mathrm{Fe}$-oxyhydroxides of stage II (Fig. 3A-H), generally followed by multiple layers of alternating colloform lithiophorite and hollandite (Fig. 3A-H). These composite masses constitute 1 to $80 \mathrm{vol} \%$ of the investigated samples. The thickness of individual layers varies from a few micrometers to several millimeters, and the transitions 
Fig. 3 Representative ore textures. (A-D) Reflected light microphotographs in air. (E-H) Back-scattered electron images. Mineral abbreviations: Ltp, lithiophorite; Hol, hollandite; Gth, goethite; Rha-Flo, rhabdophane and florencite; Qtz, quartz
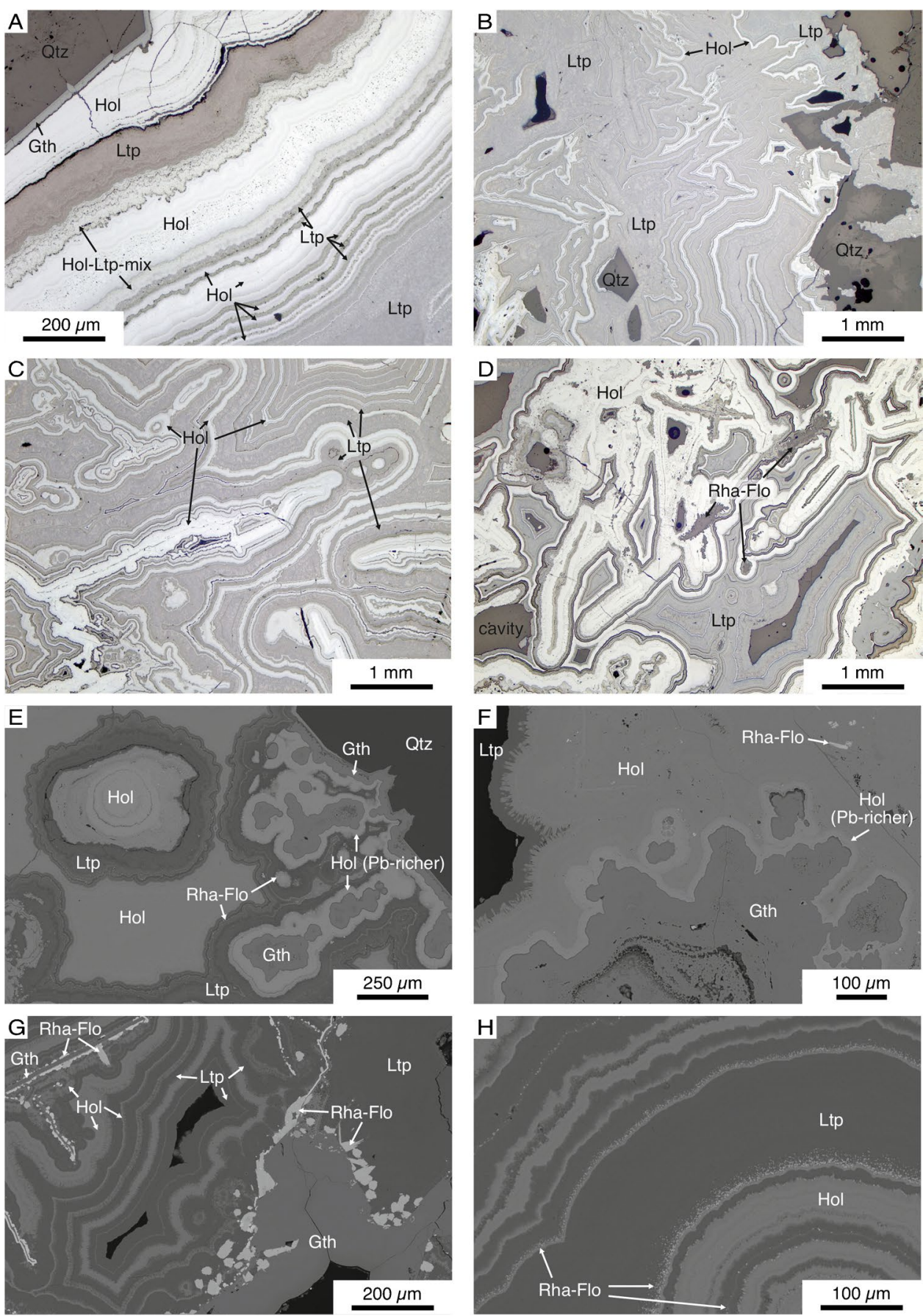

between hollandite and lithiophorite may be sharp or gradual-the latter being characterized by fine-grained intergrowths of both minerals (Fig. 3A). Rhythmic banding can be observed in most samples (Fig. 3A, C, G, H). However, the specific number of distinct hollandite and lithiophorite generations is not constant-some samples contain only one recognizable generation each of hollandite and lithiophorite, while others contain more than ten. Irrespective of the presence or absence of rhythmic banding, a general increase of lithiophorite at the expense of hollandite can be observed towards the youngest layers in all samples (Fig. 3A, C, G, $\mathrm{H})$.

Florencite and rhabdophane occur as accessory minerals in all samples (less than 1 vol.\%). They are invariably younger than the Fe-oxyhydroxides of stage II, but are older (Fig. 3D, G) than or co-genetic (Fig. 3E, H) with the Mnoxyhydroxides. They form small $(<20 \mu \mathrm{m})$ radial aggregates or elongated prismatic crystals. Occasionally, multiple 


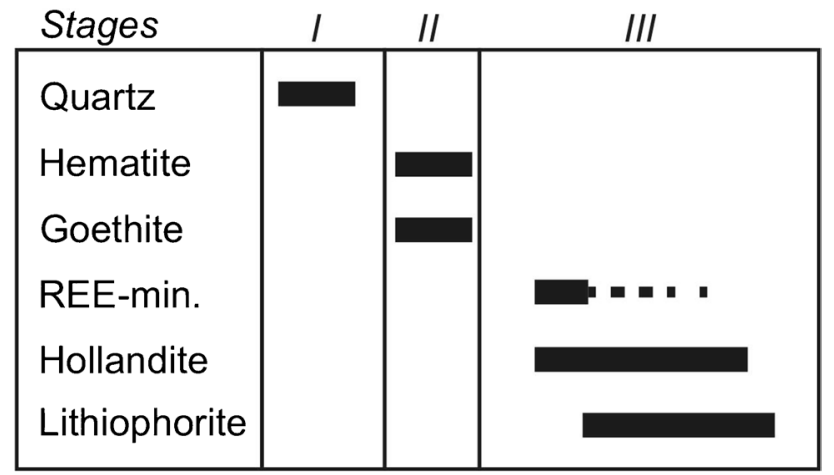

Fig. 4 Schematic paragenetic sequence

generations of LREE minerals occur as layers within hollandite and lithiophorite (Fig. 3H).

\section{Host rock assays}

Three bulk rock geochemical analyses of fresh phyllite show relatively high $\mathrm{Fe}$ concentrations of 2.6 to $4.4 \mathrm{wt}$.\%. Lithium ranges from 14 to $85 \mathrm{~g} / \mathrm{t}$, Co from 4 to $9 \mathrm{~g} / \mathrm{t}, \mathrm{Cu}$ from 11 to $17 \mathrm{~g} / \mathrm{t}, \mathrm{Ni}$ from 40 to $50 \mathrm{~g} / \mathrm{t}, \mathrm{Zn}$ from $<30$ to $90 \mathrm{~g} / \mathrm{t}$, and $\mathrm{Mn}$ from 64 to $290 \mathrm{~g} / \mathrm{t}$.

\section{Vein-infill assays}

The dataset includes grab samples with variable modal abundances of $\mathrm{Fe}-\mathrm{Mn}$-oxides ranging from 1 to 80 vol\%. Consequently, analysis results vary substantially with respect to major, minor, and trace elements. For a better evaluation of actual ore grades, we excluded all samples with Mn concentrations below $5 \mathrm{wt} \%$. Median concentrations of economically relevant elements in the remaining 30 assays are as follows: $1475 \mathrm{~g} / \mathrm{t} \mathrm{Li}, 3330 \mathrm{~g} / \mathrm{t} \mathrm{Co}, 2890 \mathrm{~g} / \mathrm{t}$ $\mathrm{Cu}, 657 \mathrm{~g} / \mathrm{t} \mathrm{Ni}$, and $918 \mathrm{~g} / \mathrm{t} \mathrm{Zn} \mathrm{(Fig.} 5$ and electronic supplement Table A1). Iron concentrations of mineralized samples range from 0.57 to $36.9 \mathrm{wt} . \%$. Manganese concentrations often exceed the quantification maximum of the used analytical program $(10,000 \mathrm{~g} / \mathrm{t})$. No effort was made to quantify these very high $\mathrm{Mn}$ contents with an alternative analytical method. The complete bulk geochemistry dataset is given in Table A1 of the electronic supplement.

\section{Mineral chemistry}

Targets of mineral chemistry studies have only been the two Mn oxyhydroxide minerals lithiophorite and hollandite-as these were expected to be the major hosts of $\mathrm{Li}$ and base metals. Manganese concentrations measured by EPMA range from 31.96 to 55.5 wt.\%. For all elements other

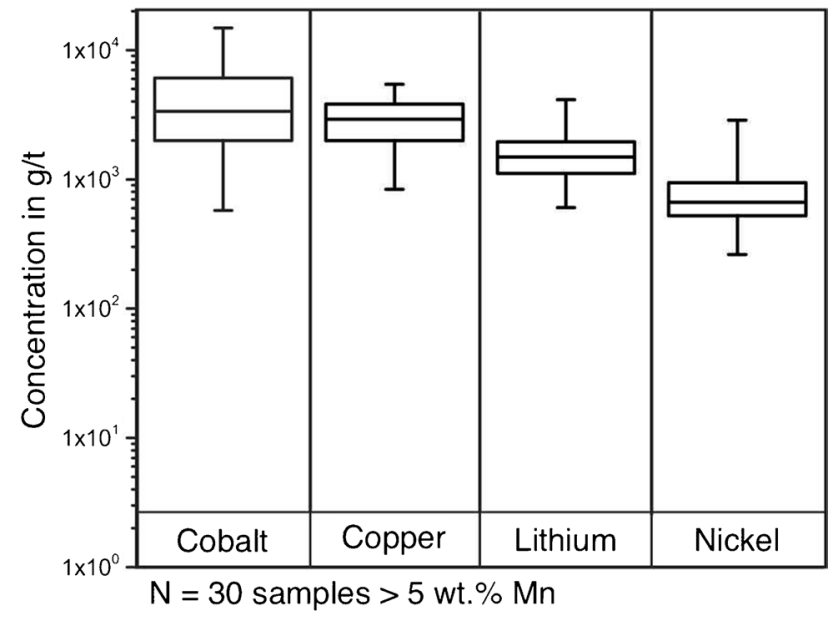

Fig. 5 Box and whiskers diagram of whole-rock concentrations of $\mathrm{Co}, \mathrm{Li}, \mathrm{Ni}$, and $\mathrm{Co}$ of 30 samples with $\mathrm{Mn}$ above 5 wt.\%

than Mn, we only present LA-ICP-MS data. This is done for analytical consistency. Detailed results for individual measurement spots analyzed by EPMA and LA-ICP-MS are provided in Tables A2 and A3 of the electronic supplement.

Due to the fine intergrowths between hollandite and lithiophorite, LA-ICP-MS measurements generally contained mixtures of the two minerals. We therefore decided to express compositional variations as a function of mineral components $\left(\mathrm{X}_{\text {lithiophorite }}=\mathrm{X}_{\mathrm{Ltp}}\right.$; Fig. 6A-I; Table 1) to be better able to visualize differences in the compositions of the pure mineral endmembers. For this purpose, the mole fraction of lithiophorite, $X_{L t p}$, was estimated as follows:

$X_{L t p}=\frac{A l+L i}{\left[(A l+L i)+\text { Const }^{*}(B a+N a+K+P b+T l)\right]}$

where element symbols represent molar concentrations of the respective elements in the sample, and Const. is a normalization constant that ensures $X_{L t p}=1$ when $X_{\text {Holl }}=0$, and $X_{\text {Holl }}=1$ when $X_{L t p}=0$.

\section{Lithiophorite}

Forty-nine analyses with an $\mathrm{X}_{\mathrm{Ltp}}>0.95$ (molar) have median values of $34.4 \mathrm{wt} . \% \mathrm{Mn}$ and $11.7 \mathrm{wt} . \% \mathrm{Al}$, whereas medians of $\mathrm{K}, \mathrm{Ba}, \mathrm{Na}, \mathrm{Sr}$, and $\mathrm{Pb}$ are below $100 \mathrm{mg} / \mathrm{kg}$ (Table 1 and electronic supplement Table A3), as expected. Lithiophorite has a median value of $5366 \mathrm{mg} / \mathrm{kg}$ of $\mathrm{Li}$. Cobalt and $\mathrm{Ni}$ median values are $11,772 \mathrm{mg} / \mathrm{kg}$ and $1018 \mathrm{mg} / \mathrm{kg}$, respectively (Fig. 6E, F). Copper and Zn concentrations are rather erratic and do not systematically correlate with $\mathrm{X}_{\mathrm{Ltp}}$; their median values are $7949 \mathrm{mg} / \mathrm{kg}$ and $2009 \mathrm{mg} / \mathrm{kg}$, respectively. 

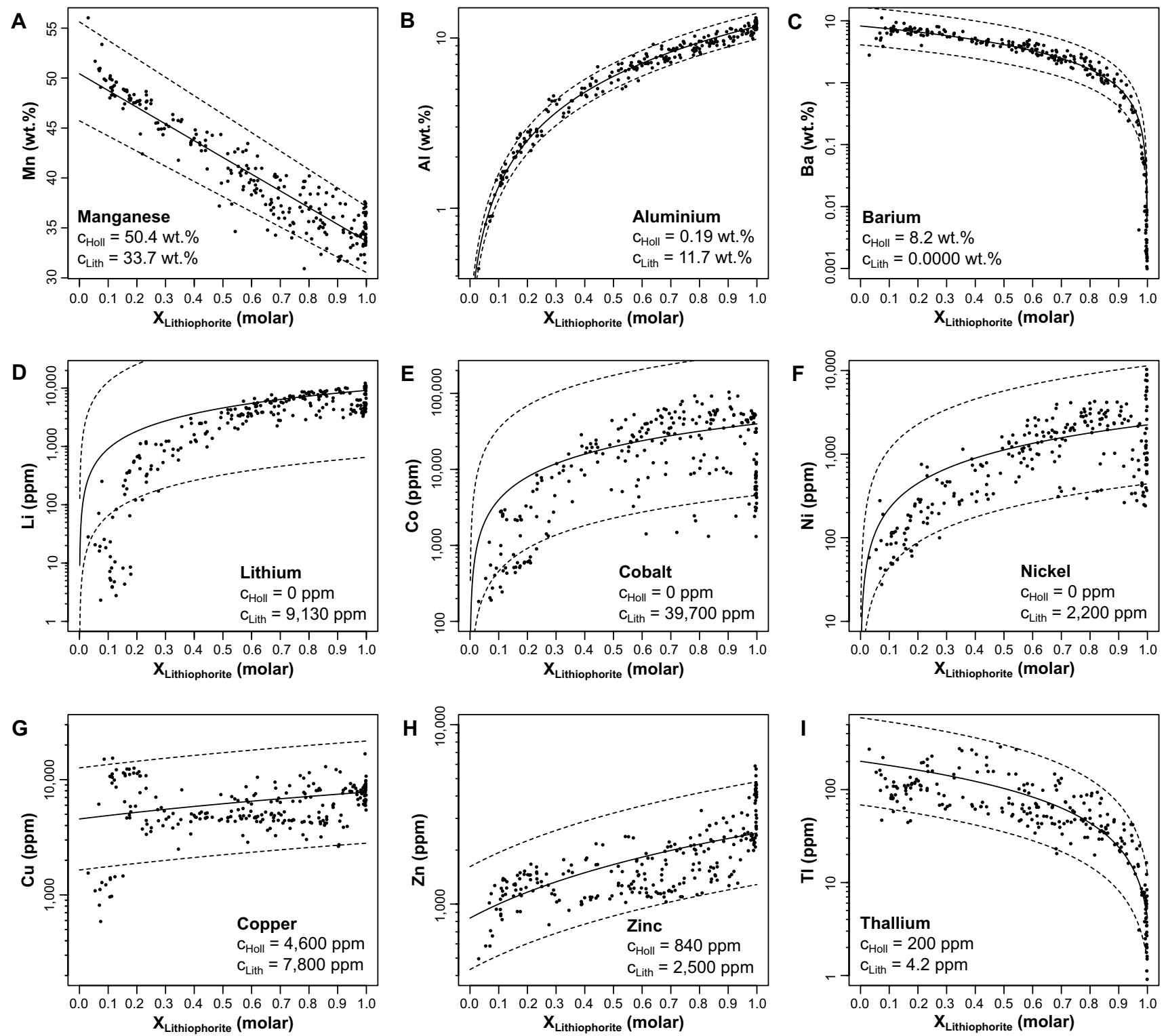

Fig. 6 Concentrations of $\mathrm{Mn}(\mathbf{A}), \mathrm{Al}(\mathbf{B}), \mathrm{Ba}(\mathbf{C}), \mathrm{Li}(\mathbf{D}), \mathrm{Co}(\mathbf{E}), \mathrm{Ni}$ $(\mathbf{F}), \mathrm{Cu}(\mathbf{G}), \mathrm{Zn}(\mathbf{H})$, and $\mathrm{Tl}(\mathbf{I})$ as a function of $\mathrm{X}_{\text {Lithiophorite }}$ Calculated mixing models are shown as straight lines. Dotted lines indicate the predicted minimum and maximum values of the mixing model (95\% probability intervals). The endmember concentrations of the mixing models are given as $\mathrm{C}_{\mathrm{Hol}}$ and $\mathrm{C}_{\mathrm{Lith}}$ in each panel

\section{Coronadite group minerals}

Since almost all analyses of hollandite contain a lithiophorite component, nine analyses with $\mathrm{X}_{\mathrm{Ltp}}<0.1$ were used to calculate mean, maximum, and minimum elemental concentrations (Table 1 and electronic supplement Table A3). As expected, hollandite contains distinctly more $\mathrm{Ba}(5.5 \mathrm{wt} . \%)$, K (1.6 wt.\%), Na (0.1 wt.\%), and $\mathrm{Sr}(477 \mathrm{mg} / \mathrm{kg}$ ) compared to lithiophorite (Fig. 6). Analyzed coronadite group minerals are best described as hollandite with a significant content of cryptomelane (Frenzel, 1980). Few analyses yield a minor coronadite component (up to $120 \mathrm{mg} / \mathrm{kg} \mathrm{Pb}$; Fig. 3E, F).
However, overall $\mathrm{Pb}$ content is low. Median values of $\mathrm{Li}$ in analyses with $X_{\mathrm{Ltp}}<0.1$ are $25 \mathrm{mg} / \mathrm{kg}$. Hollandite has low median concentrations of $354 \mathrm{mg} / \mathrm{kg}$ Co and $76 \mathrm{mg} / \mathrm{kg} \mathrm{Ni}$. Thus, the majority of $\mathrm{Li}, \mathrm{Co}$, and $\mathrm{Ni}$ is clearly hosted by lithiophorite (Fig. 6). Median values of $\mathrm{Cu}$ not only are generally lower in hollandite $(1716 \mathrm{mg} / \mathrm{kg})$ compared to lithiophorite, but also account for highest analyzed $\mathrm{Cu}$ values of up to $13,257 \mathrm{mg} / \mathrm{kg}$. Median values of $\mathrm{Zn}$ are $782 \mathrm{mg} / \mathrm{kg}$. Remarkable is the mean concentration of $\mathrm{Tl}$ of $134 \mathrm{mg} / \mathrm{kg}$ in hollandite. 


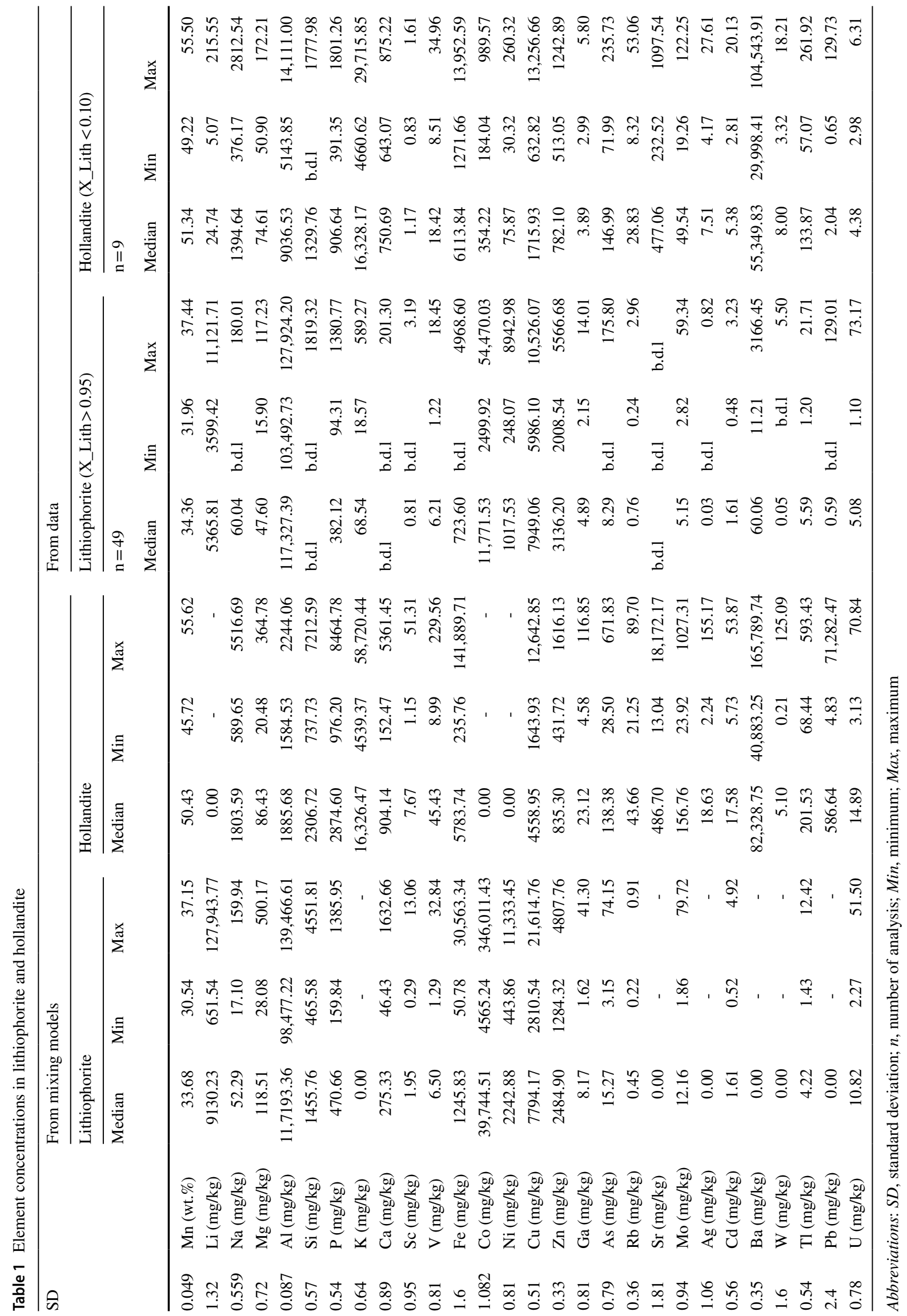




\section{${ }^{40} \mathrm{Ar} /{ }^{39} \mathrm{Ar}$ geochronology}

Results of ${ }^{40} \mathrm{Ar} /{ }^{39} \mathrm{Ar}$ measurements of three samples of Mnoxyhydroxides are summarized in Table 2 and Fig. 7 (the complete background data is provided in the electronic supplement Table 4A). Samples E03, E13, and E14 yield inverse isochron ages of $36.7 \pm 0.36,34.4 \pm 0.94$, and $40.5 \pm 0.9 \mathrm{Ma}$, respectively, with only one sample (E13) showing significant overdispersion (MSWD $=6.2$ ) with respect to the steps chosen for age calculation. The amounts of ${ }^{39} \mathrm{Ar}_{\mathrm{K}}$ included in age calculation are 58\%, 84\%, and 66\%, respectively (Fig. 7). Two samples are characterized by a slightly sub-atmospheric ${ }^{40} \mathrm{Ar} /{ }^{36} \mathrm{Ar}$ intercept (Fig. 7B, F), potentially reflecting partial argon loss, whereas one sample shows a super-atmospheric intercept, which suggests excess argon (Fig. 7D; Pfänder et al., 2014; Schaen et al., 2021). The inverse isochron intercepts have been used to recalculate the age data (Schaen et al., 2021), which results in identical weighted plateau ages (within errors) for all three samples for the same steps as used for the isochron age calculation (Table 2). Potassium/ $\mathrm{Ca}$ ratios in all three samples are highly variable from step to step, and the amount of radiogenic argon in most steps is comparatively low (often less than $50 \%$; see electronic supplement Table 4A).

\section{Discussion}

The following discussion focuses on the origin of lithiophorite-rich Li-Co-Ni-Mn mineralization at the Eichigt prospect. A sound understanding of its genesis is critical for the evaluation of the resource potential of such polymetallic mineralization in the Erzgebirge, since it may provide important clues with regard to the possible vertical extent and lateral distribution of the mineralization.

\section{Origin and timing of Li-Co-Ni-Mn mineralization}

Because exposure of mineralization at Eichigt is limited to surface samples, it is imperative to critically evaluate all observations on their genetic relevance. Although a direct genetic link between coarse crystalline hydrothermal quartz (stage 1) and distinctly younger Fe-Mn-oxyhydroxide mineralization (stages 2 and 3) at Eichigt seems unlikely, preexisting hydrothermal veins apparently acted as preferential fluid migration pathways (either ascending or descending fluids) for later oxyhydroxide mineralization. Iron- and Mnoxyhydroxides often show similar textures namely colloform, botryoidal, cavity infills, and crusts (Fig. 3), which suggests that they formed in a similar environment. Nonetheless, these textures are inconclusive and may occur in both supergene and low-temperature hydrothermal systems 

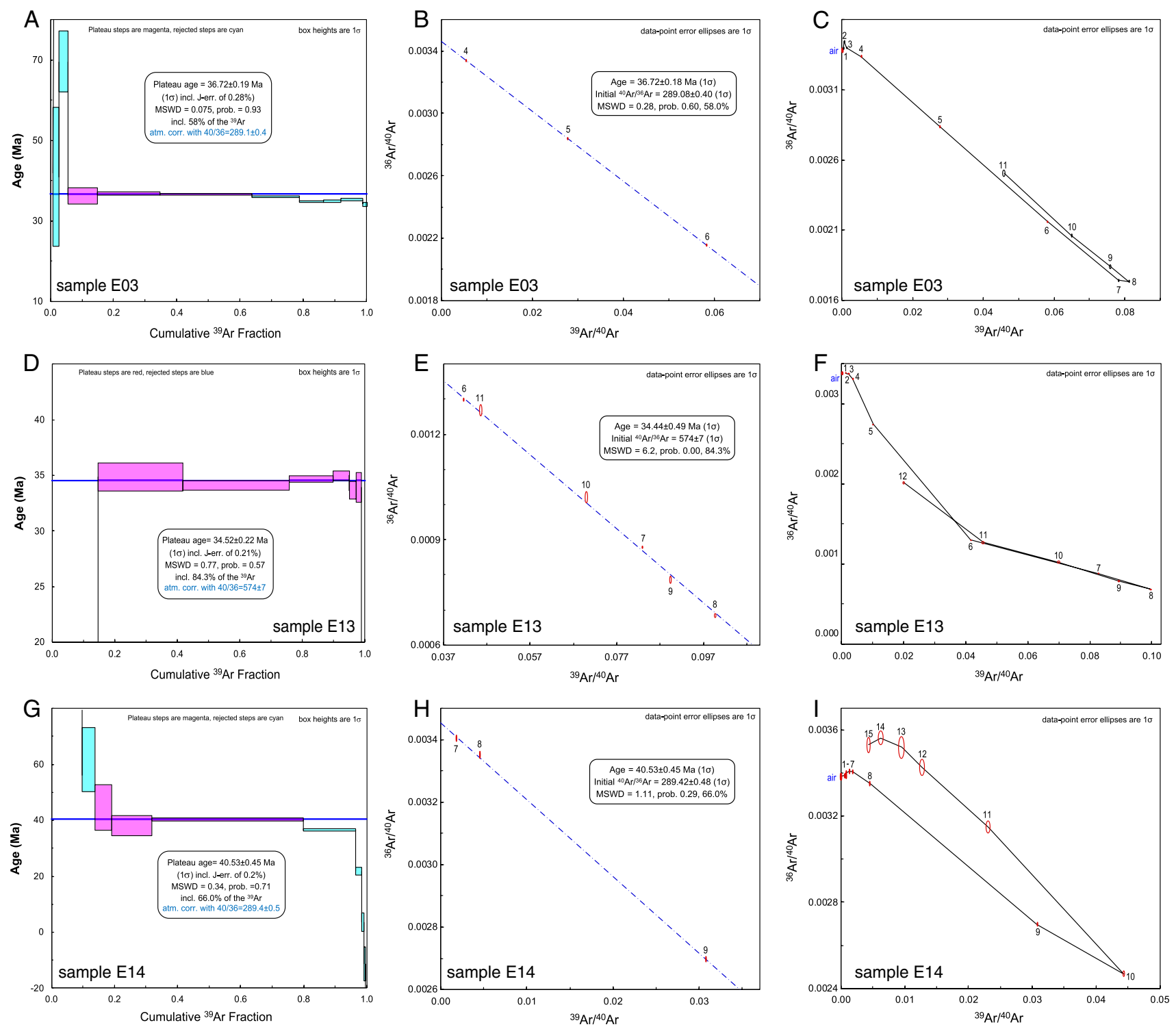

Fig. $7{ }^{40} \mathrm{Ar} /{ }^{39} \mathrm{Ar}$ age spectra $(\mathbf{A}, \mathbf{D}, \mathbf{G})$, inverse isochron diagrams showing only steps that have been used for age calculation $(\mathbf{B}, \mathbf{E}, \mathbf{H})$, and background data including all heating steps $(\mathbf{C}, \mathbf{F}, \mathbf{I})$.

(Burisch et al., 2017b; Gutzmer and Beukes, 1996; Manceau et al., 1990; Nicholson, 1992).

${ }^{40} \mathrm{Argon} /{ }^{39} \mathrm{Arg}$ on ages of coronadite group minerals from Eichigt ( $\sim 40-34 \mathrm{Ma})$ coincide with the early stage of the Cenozoic Eger graben rifting (Pälchen and Walter, 2008; Ulrych et al., 2011; Ziegler and Dèzes, 2007). Cenozoic exhumation of the Erzgebirge in response to the Eger graben rift has been constrained to at least $1 \mathrm{~km}$ during the last $50 \mathrm{Ma}$ using apatite-fission-track analyses (Lange et al., 2008). Assuming constant uplift rates, minimum formation depths of $\sim 700 \mathrm{~m}$ can be estimated for the Eichigt $\mathrm{Fe}-\mathrm{Mn}$-oxyhydroxides. The occurrence of $\mathrm{Fe}-\mathrm{Mn}$ oxyhydroxide mineralization, similar to that documented here, at $525 \mathrm{~m}$ below the present-day surface (Ktr $23 \mathrm{~A} 2 / 81$; Ilgner and Hahn (1998)) at Brunndöbra $25 \mathrm{~km}$ east of Eichigt, furthermore supports that such mineralization formed at significant depth. Considering that the depth of chemical weathering since the Cretaceous in the Erzgebirge has been constrained to only a few meters below surface, with only locally extending to several $10 \mathrm{~s}$ to a max. of $100 \mathrm{~m}$ depth (Migoń and Lidmar-Bergström, 2001), it is implied that, at least some, $\mathrm{Fe}-\mathrm{Mn}$-oxyhydroxide mineralization in the Erzgebirge formed by hydrothermal processes and far below the zone of weathering. A hydrothermal origin is also consistent with thermochronological studies, which suggest that the host rocks exposed at the surface today were as hot as $40-60{ }^{\circ} \mathrm{C}$ at $35 \mathrm{Ma}$ (Wolff et al., 2015). Our conclusion is furthermore supported by recent in situ U-Pb geochronology 
of hydrothermal carbonate minerals, which overlap with the $\mathrm{Ar}-\mathrm{Ar}$ ages of coronadite group minerals (this study) and document rift-related hydrothermal activity and widespread vein formation from 40 to $0.6 \mathrm{Ma}$ in the Erzgebirge and Schwarzwald (Burisch et al., 2018; Guilcher et al., 2021a; Walter et al., 2018). As direct evidence is however lacking and all constraints are rather indirect, a supergene origin cannot be completely discarded.

In either case, the geochronological data indicates that tectonic activity related to the Eger graben rifting enabled fluid flow - regardless whether it was ascending or descending.

Possible precipitation mechanisms for the hydrothermal $\mathrm{Mn}-\mathrm{Fe}$ oxyhydroxide mineralization include oxidation, pH increase, and/or cooling (Hem, 1972). Importantly, lithiophorite and coronadite group minerals are invariably younger than goethite and hematite - with sharp contacts between each other. This suggests that conditions (i.e., $\mathrm{pH}$, $\mathrm{fO}_{2}$, temperature) and/or fluid compositions (solutes) in the mineralizing system changed most likely abruptly, since otherwise a gradual transition, rhythmic banding, or intergrowth of $\mathrm{Fe}$ and Mn oxyhydroxides would be expected.

\section{Metal tenor and source}

Bulk rock analyses of unaltered host rock have low $\mathrm{Mn}, \mathrm{Co}$, $\mathrm{Ni}$, and $\mathrm{Cu}$ concentrations (Electronic supplement TableA1), which resembles the average composition of the continental crust (McLennan, 2001). This renders it unlikely that leaching of immediate host rocks served as metal source for polymetallic mineralization at Eichigt - even assuming small fluid/rock ratios. In situ replacement of minerals, including carbonate, sulfide, and Mn minerals, has been proposed as a potential elemental source for Co-rich lithiophorite elsewhere (Hautmann and Lippolt, 2000; Larson, 1970; Mitchell and Meintzer, 1967; Ostwald, 1984). However, boxwork and pseudomorphous textures are rare in the investigated samples, whereas irregularly shaped open-space infills and individual veinlets are significantly more abundant (Figs. 2 and 3). This suggests that only a small fraction of lithiophorite (stage III) is related to dissolution and precipitation of previously existing minerals. Epithermal- and unconformity-related veins of the Erzgebirge typically comprise a variety of $\mathrm{Pb}-\mathrm{Zn}-(\mathrm{Cu})$ $(\mathrm{Ag})$-sulfide minerals, whereas $\mathrm{Co}$ and $\mathrm{Ni}$ sulfides are rare (Burisch et al., 2019b; Guilcher et al., 2021b; Haschke et al., 2021; Swinkels et al., 2021). It seems thus unlikely that such veins could provide sufficient $\mathrm{Li}, \mathrm{Co}$, and $\mathrm{Ni}$ to account for the quantities of Mn-oxyhydroxides observed at the Eichigt prospect. Silver-Bi-Co-Ni-As (native metal-arsenide) veins are widespread across the Erzgebirge (Baumann et al., 2000; Guilcher et al., 2021b) and they comprise abundant $\mathrm{Co}-\mathrm{Ni}$ arsenide minerals. Although they could potentially provide $\mathrm{Co}$ and $\mathrm{Ni}$, in situ alteration of $\mathrm{Co}-\mathrm{Ni}$-arsenides is an unlikely cause of Li-Co-Ni-Mn-oxyhydroxide mineralization, since low-temperature hydrothermal (or supergene) overprint of native metal-arsenide veins typically results in either the formation of secondary arsenates (Markl et al. (2014); i.e., annabergite, erythrite, or hoernesite) or arsenides remain mostly undissolved even if most other minerals are dissolved (Burisch et al., 2017a) - neither arsenides nor arsenates have been recognized at Eichigt.

Based on these arguments, an external source for at least $\mathrm{Li}, \mathrm{Ni}$, and $\mathrm{Co}$ can be assumed, which is again consistent with a hydrothermal origin of polymetallic mineralization. Therefore, leaching of deeper rock units such as the proximal Schönbrunn granite (enriched in Li and LREE; Gottesmann et al. (2017)), Cenozoic basaltoids (Ni, Co, Cu), and/or dissolution of underlying vein-mineralization are tentatively identified as possible metal sources. For the latter case, lithiophorite mineralization could potentially serve as a pathfinder for hydrothermal vein mineralization at greater depth.

\section{Genesis of polymetallic oxide mineralization at Eichigt}

Field observations, geochronology, and the geological context suggest that $\mathrm{Li}-\mathrm{Co}-\mathrm{Ni}-\mathrm{Mn}$ mineralization at Eichigt most likely represents shallow crustal vein-type mineralization related to hydrothermal activity associated with the Cenozoic Eger graben rifting. Ongoing mantle-derived exhalation of $\mathrm{CO}_{2}$ is documented for the Eger graben rift system (Kämpf et al., 2013). Interaction of $\mathrm{CO}_{2}$ with hydrothermal fluids may result in acidification of these fluids (Paces and Smejkal, 2014; Pauwels et al., 1993; Sanjuan et al., 2016), which significantly increases their capacity to transport $\mathrm{Mn}, \mathrm{Co}$, and $\mathrm{Ni}$ at low temperatures. During ascent of such $\mathrm{CO}_{2}$ - and metal-rich fluids along pre-existing (quartz- and sulfide-mineralized) fracture systems, the associated pressure decrease may have led to $\mathrm{CO}_{2}$ effervessence; this would result in neutralization of the fluid and precipitation of Li-Co-Ni-Mn mineralization. Changes in $\mathrm{fO}_{2}$ and cooling caused by, e.g., dilution of hydrothermal fluids with shallow groundwater could also be relevant factors for mineral precipitation. The temperature of the ore-forming fluid is due to the lack of direct evidence difficult to constrain. Based on thermochronological studies (Wolff et al., 2015), temperatures between 70 and $35^{\circ} \mathrm{C}$ seem likely.

\section{Conclusions}

Significant concentrations of Co $(0.6-14.7 \mathrm{~kg} / \mathrm{t}), \mathrm{Li}$ $(0.6-4.1 \mathrm{~kg} / \mathrm{t}), \mathrm{Ni}(0.2-2.8 \mathrm{~kg} / \mathrm{t}), \mathrm{Cu}(0.8-5.4 \mathrm{~kg} / \mathrm{t}), \mathrm{Mn}$, and LREE qualify the polymetallic mineralization related to structurally controlled botryoidal Fe-Mn oxyhydroxide mineralization at Eichigt as a potential "battery ore." As 
such, it could be of both economic and strategic importance considering the increasing future demands of $\mathrm{Li}, \mathrm{Co}, \mathrm{Ni}$, and Mn for battery production in Central Europe. Observations from Eichigt as well as data from similar mineralization at other sites in the Variscan Orogen suggest this polymetallic mineralization to be of low temperature hydrothermal rather than supergene - origin. This, in turn, would suggest a possible extent towards depth well below the current limit of chemical weathering. Moreover, a hydrothermal origin implies that Li-Co-Ni-Mn-mineralization is related to ascending rather than descending fluids. The metal tenor may thus serve as a pathfinder to further hydrothermal mineralization deeper below the present-day land surface. Exploration drilling would be required to test this hypothesis and to evaluate the resource potential of the Eichigt prospect.

Supplementary Information The online version contains supplementary material available at https://doi.org/10.1007/s00126-021-01061-4.

Acknowledgements We are grateful to Elisa-Marie Hassel for support with fieldwork and sampling. Special thanks to Blanka Sperner for carrying out the Ar-Ar analyses, data processing, and age calculations, and to the Reactor Services Division of the Centrum Výzkumu in Rež, Czech Republik, for performing the neutron irradiation of the samples for Ar-Ar dating. Marcus Oelze acknowledges the financial support of the Helmholtz Recruitment Initiative to Sarah A. Gleeson. Furthermore, we would like to thank Raymond Burgess, Walter K. Witt, Harilaos Tsikos, Paolo Fulignati, and Paulo Vasconcelos for constructive reviews. We also would like to thank Bernd Lehmann, Alexandre Cabral, and Steffen Hagemann for the editorial handling.

Funding Open Access funding enabled and organized by Projekt DEAL. This study was partly funded by Lithium Australia NL, the European Social Fund and the Federal State of Saxony (Grant No. 100339454 to Mathias Burisch).

Open Access This article is licensed under a Creative Commons Attribution 4.0 International License, which permits use, sharing, adaptation, distribution and reproduction in any medium or format, as long as you give appropriate credit to the original author(s) and the source, provide a link to the Creative Commons licence, and indicate if changes were made. The images or other third party material in this article are included in the article's Creative Commons licence, unless indicated otherwise in a credit line to the material. If material is not included in the article's Creative Commons licence and your intended use is not permitted by statutory regulation or exceeds the permitted use, you will need to obtain permission directly from the copyright holder. To view a copy of this licence, visit http://creativecommons.org/licenses/by/4.0/.

\section{References}

Bauer M, Burisch M, OstendorfKrause JJ, Frenzel M, Seifert T, Gutzmer J (2019) Trace element geochemistry of sphalerite in contrasting hydrothermal fluid systems of the Freiberg district, Germany: insights from LA-ICP-MS analysis, near-infrared light microthermometry of sphalerite-hosted fluid inclusions and sulfur isotope geochemistry. Mineralium Deposita 2:237-262
Baumann, L., Kuschka, E., and Seifert, T., 2000, Lagerstätten des Erzgebirges: Stuttgart, Enke im Thieme-Verlag, 300 p.

Biagioni C, Capalbo C, Pasero M (2012) Nomenclature tunings in the hollandite supergroup. European Journal of Mineralogy 25:85-90

Burisch M, Gerdes A, Meinert LD, Albert R, Seifert T, Gutzmer J (2019) The essence of time-fertile skarn formation in the Variscan Orogenic Belt. Earth and Planetary Science Letters 519:165-170

Burisch M, Gerdes A, Walter BF, Neumann U, Fettel M, Markl G (2017) Methane and the origin of five-element veins: mineralogy, age, fluid inclusion chemistry and ore forming processes in the Odenwald. SW Germany: Ore Geology Reviews 81:42-61

Burisch M, Hartmann A, Bach W, Krolop P, Krause J, Gutzmer J (2019) Genesis of hydrothermal silver-antimony-sulfide veins of the Bräunsdorf sector as part of the classic Freiberg silver mining district, Germany. Mineralium Deposita 54:263-280

Burisch M, Walter BF, Gerdes A, Lanz M, Markl G (2018) Latestage anhydrite-gypsum-siderite-dolomite-calcite assemblages record the transition from a deep to a shallow hydrothermal system in the Schwarzwald mining district. SW Germany: Geochimica Et Cosmochimica Acta 223:259-278

Burisch M, Walter BF, Markl G (2017) Silicification of hydrothermal gangue minerals in $\mathrm{Pb}-\mathrm{Zn}-\mathrm{Cu}$-fluorite-quartz-baryte veins. Canadian Mineralogist 55:501-514

Crespo A, Lunar R (1997) Terrestrial hot-spring Co-rich Mn mineralization in the Pliocene-Quaternary Calatrava region (central Spain): Geological Society. London, Special Publications 119:253-264

De Villiers JE (1945) Lithiophorite from the Postmasburg manganese deposits: American Mineralogist. Journal of Earth and Planetary Materials 30:629-634

Dupalová T, Sracek O, Vencelides Z, Žák K (2012) The origin of thermal waters in the northeastern part of the Eger Rift. Czech Republic: Applied Geochemistry 27:689-702

Dzemua GL, Gleeson SA, Schofield PF (2013) Mineralogical characterization of the Nkamouna $\mathrm{Co}-\mathrm{Mn}$ laterite ore, southeast Cameroon. Mineralium Deposita 48:155-171

Frenzel A (1870) Lithiophorit, ein lithionhaltiges Manganerz. Journal für praktische Chemie 2:203-206

Frenzel, G., 1980, The manganese ore minerals, in Graselly, G., and Varentsoc, I., eds., Geology and geochemistry of manganese: Stuttgart, Schweizerbart, p. 25-157.

Giesler, T., Tietz, O., and Witzke, T., 2017, Vererzungen in Quarzgängen des Görlitzer Schiefergebirges-Neufunde beim Bau der Windkraftanlagen nördlich von Görlitz.

Gottesmann B, Förster HJ, Müller A, Kämpf H (2017) The concealed granite massif of Eichigt-Schönbrunn (Vogtland, Germany): petrography, mineralogy, geochemistry and age of the Eichigt apical intrusion. Freiberg Online Geoscience 49:1-46

Gruber, A., 2018, The Eichigt Exploration Report: West Perth, Lithium Australia LN.

Guilcher, M., Albert, R., Gerdes, A., Gutzmer, J., and Burisch, M., 2021a, LA-ICP-MS U-Pb geochronology of carbonates from Ag-Bi-Co-Ni-As-U veins in the Erzgebirge (Germany and Czech Republic): new insights into the timing of mineralization, PDAC Conference: Toronto, Canada.

Guilcher, M., Schmaucks, A., Krause, J., Markl, G., Gutzmer, J., and Burisch, M., 2021b, Vertical zoning in hydrothermal U-Bi-CoNi-As-Ag systems - a case study from the Annaberg-Buchholz District, Erzgebirge (Germany): Economic Geology, v. in press.

Gutzmer J, Beukes NJ (1996) Karst-hosted fresh-water Paleoproterozoic manganese deposits. Postmasburg, South Africa: Economic Geology 91:1435-1454

Haschke, S., Gutzmer, J., Wohlgemuth-Ueberwasser, C. C., Kraemer, D., and Burisch, M., 2021, The Niederschlag fluorite-(barite) deposit, Erzgebirge/Germany-a fluid inclusion and trace element study: Mineralium Deposita, p. 1-16. 
Hautmann S, Lippolt HJ (2000) 40Ar/39Ar dating of central European $\mathrm{K}-\mathrm{Mn}$ oxides - a chronological framework of supergene alteration processes during the Neogene. Chemical Geology 170:37-80

Hem JD (1972) Chemical factors that influence the availability of iron and manganese in aqueous systems. Geological Society of America Bulletin 83:443-450

Hewett DF, Cornwall HR, Erd RC (1968) Hypogene veins of gibbsite, pyrolusite, and lithiophorite in Nye County Nevada. Economic Geology 63:360-371

Ilgner E-M, Hahn W (1998) Die Schwerspatlagerstätte Brunndöbra und das Schwerspatvorkommen Schnarrtanne im Ostvogtland/Westerzgebirge. Sächsisches Landesamt für Umwelt, Landwirtschaft und Geologie, Freiberg. 114 pages.

Jones SA (2017) Geology and geochemistry of fault-hosted hydrothermal and sedimentary manganese deposits in the Oakover Basin, east Pilbara. Western Australia: Australian Journal of Earth Sciences 64:63-102

Kämpf H, Bräuer K, Schumann J, Hahne K, Strauch G (2013) CO2 discharge in an active, non-volcanic continental rift area (Czech Republic): characterisation $(813 \mathrm{C}, 3 \mathrm{He} / 4 \mathrm{He})$ and quantification of diffuse and vent CO2 emissions. Chemical Geology 339:71-83

Kröner A, Willner AP (1998) Time of formation and peak of Variscan HP-HT metamorphism of quartz-feldspar rocks in the central Erzgebirge. Saxony, Germany: Contributions to Mineralogy and Petrology 132:1-20

Kuschka E (1997) Atlas der hydrothermalite des Vogtlandes, Erzgebirges und Granulitgebirges. Geoprofil 7. Sächsisches Landesamt für Umwelt und Geologie, Bereich Boden und Geologie, Freiberg. 151 pages.

Kuschka E (2002) Zur Tektonik, Verbreitung und Minerogenie sächsischer hydrothermaler Mineralgänge. Geoprofil 11. Sächsisches Landesamt für Umwelt und Geologie, Freiberg. 183 pages.

Lange, J.-M., Tonk, C., and Wagner, G. A., 2008, Apatite fission track data for the Postvariscan thermotectonic evolution of the Saxon basement first results, v. 159, p. 123-132.

Larson LT (1970) Cobalt-and nickel-bearing manganese oxides from the Fort Payne Formation, Tennessee. Economic Geology 65:952-962

Lee JY, Marti K, Severinghaus JP, Kawamura K, Yoo HS, Lee JB, Kim JS (2006) A redetermination of the isotopic abundances of atmospheric Ar. Geochimica et Cosmochimica Acta 70:4507-4512

Ludwig, K., 2008, Manual for Isoplot 3.7: Berkeley Geochronology Center Special Publication 4, California.

Manceau A, Buseck PR, Miser DE, Rask J, Nahon D (1990) Characterization of $\mathrm{Cu}$ in lithiophorite from a banded $\mathrm{Mn}$ ore. American Mineralogist 75:490-494

Manceau A, Llorca S, Calas G (1987) Crystal chemistry of cobalt and nickel in lithiophorite and asbolane from New Caledonia. Geochimica et Cosmochimica Acta 51:105-113

Markl G, Marks MAW, Derrey I (2014) Weathering of cobalt arsenides: natural assemblages and calculated stability relations among secondary $\mathrm{Ca}-\mathrm{Mg}-\mathrm{Co}$ arsenates and carbonates. American Mineralogist 99:44-56

McLennan, S. M., 2001, Relationships between the trace element composition of sedimentary rocks and upper continental crust: Geochemistry, Geophysics, Geosystems, v. 2.

Migoń P, Lidmar-Bergström K (2001) Weathering mantles and their significance for geomorphological evolution of central and northern Europe since the Mesozoic. Earth-Science Reviews $56: 285-324$

Mitchell RS, Meintzer RE (1967) Lithiophorite from Charlottesville, Virginia. American Mineralogist 52:1545-1549

Nicholson K (1992) Contrasting mineralogical-geochemical signatures of manganese oxides; guides to metallogenesis. Economic Geology $87: 1253-1264$
Osbahr I, Krause J, Bachmann K, Gutzmer J (2015) Efficient and accurate identification of platinum-group minerals by a combination of mineral liberation and electron probe microanalysis with a new approach to the offline overlap correction of platinumgroup element concentrations. Microscopy and Microanalysis 21:1080-1095

Ostendorf J, Henjes-Kunst F, Seifert T, Gutzmer J (2019) Age and genesis of polymetallic veins in the Freiberg district, Erzgebirge, Germany: constraints from radiogenic isotopes. Miner Deposita $54: 217-236$

Ostwald J (1984) Two varieties of lithiophorite in some Australian deposits. Mineralogical Magazine 48:383-388

Paces, T., and Smejkal, V., 2014, Magmatic and fossil components of thermal and mineral waters in the Eger River continental rift (Bohemian massif, central Europe): Dams and Appurtenant Hydraulic Structures, p. 167.

Pälchen W, Walter H (2008) Geologie von Sachsen: Geologischer Bau und Entwicklungsgeschichte. Schweitzerbart und Gebr. Borntraeger, Stuttgart. 537 pages.

Paton C, Hellstrom J, Paul B, Woodhead J, Hergt J (2011) Iolite: freeware for the visualisation and processing of mass spectrometric data. Journal of Analytical Atomic Spectrometry 26:2508-2518

Pauwels H, Fouillac C, Fouillac AM (1993) Chemistry and isotopes of deep geothermal saline fluids in the Upper Rhine Graben: origin of compounds and water-rock interactions. Geochimica et Cosmochimica Acta 57:2737-2749

Pfänder JA, Sperner B, Ratschbacher L, Fischer A, Meyer M, Leistner M, Schaeben H (2014) High-resolution 40Ar/39Ar dating using a mechanical sample transfer system combined with a high-temperature cell for step heating experiments and a multicollector ARGUS noble gas mass spectrometer: Geochemistry. Geophysics, Geosystems 15:2713-2726

Rao D, Nayak B, Acharya B (2010) Cobalt-rich lithiophorite from the Precambrian Eastern Ghats manganese ore deposit of Nishikhal, south Orissa, India. Mineralogia 41:11-21

Renne PR, Mundil R, Balco G, Min K, Ludwig K (2010) Joint determination of $40 \mathrm{~K}$ decay constants and $40 \mathrm{Ar}^{*} / 40 \mathrm{~K}$ for the Fish Canyon sanidine standard, and improved accuracy for $40 \mathrm{Ar} / 39 \mathrm{Ar}$ geochronology. Geochimica et Cosmochimica Acta 74:5349-5367

Roetzler, K., Schumacher, R., Maresch, W. V., and Willner, A. P., 1998, Characterization and geodynamic implications of contrasting metamorphic evolution in juxtaposed high-pressure units of the Western Erzgebirge (Saxony, Germany): European Journal of Mineralogy, p. 261-280.

Sächsisches Landesamt für Umwelt, L. u. G., 1994, Geologische Übersichtskarte 1:400.000: Freiberg.

Sanjuan B, Millot R, Innocent C, Dezayes C, Scheiber J, Brach M (2016) Major geochemical characteristics of geothermal brines from the Upper Rhine Graben granitic basement with constraints on temperature and circulation. Chemical Geology 428:27-47

Schaen AJ, Jicha BR, Hodges KV, Vermeesch P, Stelten ME, Mercer CM, Phillips D, Rivera TA, Jourdan F, Matchan EL (2021) Interpreting and reporting 40Ar/39Ar geochronologic data. Bulletin 133:461-487

Schuppan, W., 1968, Die kontaktmetamorphe Veränderung der ordovizischen Serien im südwestlichen und westlichen Bereich des Bergener Granits, TU Bergakademie Freiberg.

Štemprok M (1967) Genetische Probleme der Zinn-Wolfram-Vererzung im Erzgebirge. Mineralium Deposita 2:102-118

Swinkels LJ, Schulz-Isenbeck J, Frenzel M, Gutzmer J, Burisch M (2021) Spatial and temporal evolution of the Freiberg epithermal Ag-Pb-Zn district. Economic Geology, Germany

Tischendorf, G., Wasternack, J., Balduan, H., and Bein, E., 1965, Zur Lage der Granitoberfläche im Erzgebirge und Vogtland mit Bemerkungen über ihre Bedeutung für die Verteilung der 
endogenen Lagerstätten: ZEITSCHRIFT FUR ANGEWANDTE GEOLOGIE, v. H, p. 410-423.

Ulrych J, Dostal J, Adamovič J, Jelínek E, Špaček P, Hegner E, Balogh K (2011) Recurrent Cenozoic volcanic activity in the Bohemian Massif (Czech Republic). Lithos 123:133-144

UNCATAD, 2020, Commodities at a glance - special issue on strategic battery raw materials: Geneva, United Nations, p. 62.

Verplanck PL, Hitzman MW (2016) Rare earth and critical elements in ore deposits. In: Verplanck PL, Hitzman MW (eds) Rare earth and critical elements in ore deposits, 18: Littleton. Society of Economic Geologists, USA, pp 1-5

Vylita T, Žák K, Cílek V, Hercman H, Mikšíková L (2007) Evolution of hot-spring travertine accumulation in Karlovy Vary/Carlsbad (Czech Republic) and its significance for the evolution of Teplá valley and Ohře/Eger rift. Zeitschrift für Geomorphologie 51:427-442

Walter BF, Gerdes A, Kleinhanns IC, Dunk1 I, von Eynatten H, Kreissl S, Markl G (2018) The connection between hydrothermal fluids, mineralization, tectonics and magmatism in a continental rift setting: fluorite $\mathrm{Sm}-\mathrm{Nd}$ and hematite and carbonates $\mathrm{U}-\mathrm{Pb}$ geochronology from the Rhinegraben in SW Germany. Geochimica et Cosmochimica Acta 240:11-42

Wolff R, Dunkl I, Lange JM, Tonk C, Voigt T, von Eynatten H (2015) Superposition of burial and hydrothermal events: post-Variscan thermal evolution of the Erzgebirge, Germany. Terra Nova-Oxford 27:292-299

Zhang R, Lehmann B, Seltmann R, Sun W, Li C (2017) Cassiterite $\mathrm{U}-\mathrm{Pb}$ geochronology constrains magmatic-hydrothermal evolution in complex evolved granite systems: the classic Erzgebirge tin province (Saxony and Bohemia). Geology 45:1095-1098

Ziegler PA, Dèzes P (2007) Cenozoic uplift of Variscan Massifs in the Alpine foreland: timing and controlling mechanisms. Global and Planetary change 58:237-269

Publisher's note Springer Nature remains neutral with regard to jurisdictional claims in published maps and institutional affiliations. 